\title{
Wetlands of the Volhynian Polissia (Western Ukraine): classification, natural conditions of distribution and spatial difference
}

\author{
Tatiana SOLOVEY ${ }^{1, *}$ \\ 1 Polish Geological Institute - National Research Institute, Rakowiecka 4, 00-975 Warszawa, Poland
}

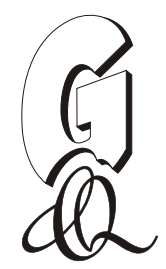

Solovey, T., 2019. Wetlands of the Volhynian Polissia (Western Ukraine): classification, natural conditions of distribution and spatial difference. Geological Quarterly, 63 (1): 139-149, doi: 10.7306/gq.1455

\begin{abstract}
The post-glacial areas are characterized by favorable conditions for the formation of wetlands as a result of the widespread occurrence of depressions without outflow - center for the development of wetlands. The studies of morphogenetic conditions of the wetland development in Volhynian Polissia within the territory of Ukraine and the formation of their water regime reveal several features of their distribution and typological variety. The location of wetlands were characterized in reference to the shape of base/subsoil and its lithology. The typical structure of post-lacustrine, paludificational, riverside and spring peatlands of the Volhynian Polissia were shown and their development were also discussed. The wetland evolution under the influence of the postglacial landscape degradation leads to disappearance of the depression wetlands in glacial forms, increase of the peat bog trophicity and the level of peat dissolution. The supply conditions and characteristics of water regime are determined for separate peatlands. According to the origin and water flow/supply four types of wetland were extracted: ombrogenic, topogenic, soligenic and fluviogenic. It was found that the reasons of the high marshes areas (21\%) in Volhynian Polissia are the geological and geomorphological conditions retaining/stopping the runoff and also local groundwater circulation system.
\end{abstract}

Key words: wetlands, classification, spatial distribution, morphologic-genetic and factor analysis, water regime, Volhynian Polissia.

\section{INTRODUCTION}

The term "wetland" has a broad meaning. It is the most often determined on the basis of the ecosystem approach (Haslam, 2003; Łachacz, 2004; Mitsch and Gosselink, 2007; Mitsch et al., 2009). Wetland - is the territory with an excessive humidification with hydrophilic vegetation and organic soils. Wetlands are transient ecosystems between typical aquatic and typical terrestrial systems being located on their border and formed under the permanent or periodical waterlogging of land surface that contributes to hydrophilic vegetation and accumulation of organic soils. There are numerous different definitions of wetlands such as "bogs and fens" (peat-accumulating wetlands), marshes' (herbaceous, frequently inundated wetlands) or "swamps" (forested wetlands), and no standardization of these terms.

According to the Ramsar Convention Secretariat (2013), wetlands are areas where water is the primary factor controlling the environment and the associated plant and animal life. They occur where the water table is at or near the surface of the land, or where the land is covered by shallow water. Thus the Ramsar Convention defines wetlands types of wetlands:

\footnotetext{
*E-mail: tatiana.solovey@pgi.gov.pl
}

Received: September 26, 2018; accepted: January 14, 2019; first published online: March 14, 2019
- coastal (marine) wetlands including coastal lagoons, rocky shores, and coral reefs;

- estuarine wetlands including deltas, tidal marshes, and mangrove swamps;

- lacustrine wetlands;

- riverine wetlands along rivers and stream;

- palustrine wetlands, include any inland wetland that lacks flowing water. Wetlands within this category include inland marshes and swamps as well as peatland (bogs and fens).

The first classification of wetlands based on the trophicity of wetland ecosystems was suggested by Schimper in 1889 (Wheeler and Proctor, 2000). While determining the relevance of wetlands to the classification, several basic issues are addressed:

- geomorphic setting;

- substrate type (soils);

- origin of water;

- trophicity;

- vegetation.

The determinant morphogenesis factor of the wetland basin (glacial, fluvial, karst, tectonic) and its form are the primary criteria of the wetland classification (Okruszko et al., 2001; Solovey, 2013). Geomorphological structure affects water conditions that, in turn, through hydrological type of nutrient supply and hydroecological conditions determine the formation of subsequent wetland types in different forms of relief (Solovey, 2013).

The existent hydrological classification involves several elements of water conditions of wetland systems: 
- type of water recharge;

- type of inflow and outflow of waters;

- intensity of water exchange.

In regards to the sources of water supply, wetlands are divided into two groups:

- wetlands that are supplied only by precipitation;

- wetlands with a mixed supply including underground and surface waters.

The most common classification in Europe is based on the work of Gilvear and Mclnnes (1994), who suggested the wetland division into 4 types on the basis of the water recharge:

- ombrogenic - dependent only on precipitation;

- rheogenic - fed by surface waters and precipitation;

- minerogenic - dependent on underground waters and precipitation;

- omnigenic - fed by underground, surface waters and precipitation.

The stagnation and running regimes of water exchange in response to the intensity of water exchange are distinguished (Yvanov, 1975). The wetland classification in Poland is built around the concept proposed by Okruszko (Okruszko, 1992; Dembek and Oświt, 1992; Dembek, 2000) who considers 4 types:

- fluviogenic - recharge mainly by river waters;

- soligenic - recharge by running groundwater that come from aquifers in the surrounding areas;

- topogenic - also dependent on the recharge by groundwater but, in comparison with previous, the water flow is almost absent. Wetlands are formed in the places where aquifers comes to the surface and with a minimal slope that contributes to the stagnant water regime;

- ombrogenic - mainly recharge by precipitation due to the location in the isolated depressions. They are formed in the conditions of the prevalence of precipitation above evapotranspiration and a difficult water outflow.

The wetland classification on the basis of trophicity is performed according to the saturation of water environment with nutrients for vegetation: nitrogen, phosphorus and potassium. Poor on nutrients wetlands are referred to oligotrophic, the ones with medium nutrient availability - mesotrophic and rich on nutrients - eutrophic (Cowardin et al., 1979). Given these features, two main ecological types of peatlands are distinguished: fens (meso- and eutrophic) and raised bogs (oligitrophic). The third ecological type - poor fens - is positioned between the mentioned earlier two types. Insufficient oligotrophic features are characteristic of these poor fens. They often serve the transient stage in the process of transformation of fens into the raised bogs (Tobolski, 2000; Ilnicki, 2002; Pawlaczyk et al., 2001, 2005; Jermaczek et al., 2009).

The majority of geobotanists consider the ecological and phytocenotic classification of wetlands since it concerns the relationships between wetland vegetation and the growth environment (Westlake et al., 2012). The following syntaxons are used in the classification: class of formations, group of formations, formation and association (Grygora et al., 2005).

Examples of the most useful wetland classification systems have been presented in Table 1.

The most comprehensive and multi-criteria classification is the classification proposed by Bertrand et al. (2012) using four parameters: pedological, morphological, hydrological and nutritive.

Wetlands of the Volhynian Polissia within Ukraine are described in the set of scientific works (Tanfiliev, 1895; Zerov, 1938; Kulczyński, 1939a, b; Dokuchaev, 1949; Bachurina, 1964; Bradis and Bachurina, 1969; Balashov and Kucheryava, 1974; Ilyin, 2004; Ilyina, 2004, 2005; Grygora et al., 2005; Solovey, 2013). Since the publication of "Forest wetlands of Ukrainian Polissia" (Grygora et al., 2005) there has been no publication where the comprehensive classification of wetlands of the Volhynian Polissia on the basis of relevant inventory data would have been provided.

The aim of the study is to analyse natural conditions of distribution of wetlands of Volhynian Polissia within Ukraine to generate diagnostic and classification structuration of wetlands and peculiarities of their spatial organisation.

\section{STUDY AREA}

The study area covers the Volhynian Polissia within Ukraine. The region of Volhynian Polissia is one of the marshiest regions of Ukraine. Wetlands constitute almost 633,000 hectares that is $21.2 \%$ of the whole Volhynian Polissia area (Solovey, 2013). The territory is the physical and geographical region of Central European lowlands with the area of $30,000 \mathrm{~km}^{2}$ on the border of Poland, Ukraine, and Belarus

Parameters used in some published wetland classification schemes

\begin{tabular}{|c|c|c|}
\hline References cited in the text & Classification parameter & Example \\
\hline Cowardin et al. (1979) & $\begin{array}{l}\text { type of system } \\
\text { type of flooding } \\
\text { modifiers }\end{array}$ & $\begin{array}{c}\text { marine, estuarine, riverine } \\
\text { permanent, intertidal } \\
\mathrm{pH}, \text { salinity }\end{array}$ \\
\hline Okruszko (1992) & $\begin{array}{l}\text { type of hydrogenous site } \\
\text { geomorphic-hydrological conditions }\end{array}$ & $\begin{array}{c}\text { peatlands, alluvial mineral marshes, telmatic organic marshes, } \\
\text { periodic moistlands } \\
\text { fluviogenic, soligenic, topogenic, ombrogenic }\end{array}$ \\
\hline Brinson (1993) & $\begin{array}{l}\text { geomorphic settings } \\
\text { origin of water } \\
\text { hydrodynamics } \\
\end{array}$ & $\begin{array}{c}\text { slope, domes } \\
\text { precipitation, surface waters, groundwater } \\
\text { vertical fluctuations, unidirectional flow }\end{array}$ \\
\hline Gilvear and Mclnnes (1994) & origin of water & ombrogenic, rheogenic, minerogenic, omnigenic \\
\hline Davies and Anderson (2001) & $\begin{array}{l}\text { geomorphic-hydrological conditions } \\
\text { origin of water } \\
\text { gross form and topography } \\
\text { microtopographic features }\end{array}$ & $\begin{array}{c}\text { depression, channeled water flow } \\
\text { ombrotrophic, minerogenic } \\
\text { flat, concave } \\
\text { presence of pools }\end{array}$ \\
\hline Ilnicki (2002) & type of soil & mineral, peat \\
\hline Bertrand et al. (2012) & type of ecosystem & $\begin{array}{c}\text { spring ecosystem, surface-water ecosystem, peatland, ground- } \\
\text { water-dependent terrestrial ecosystem }\end{array}$ \\
\hline
\end{tabular}




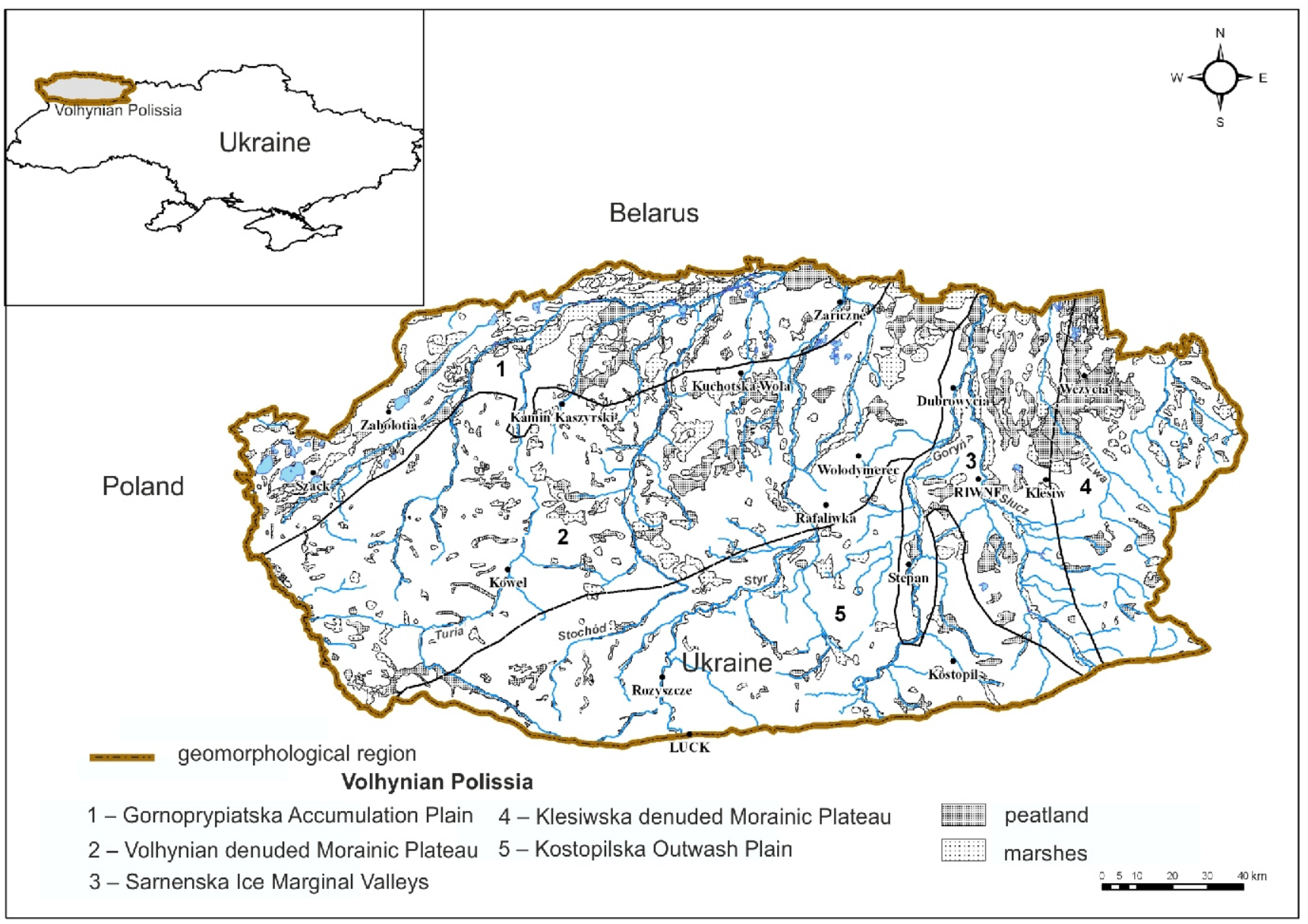

Fig. 1. Location of wetlands in the Volhynian Polissia within Ukraine

(Fig. 1). The river valley of Buh serves the boundary on the west, the hills of the Ukrainian Shield - the boundary on the east, the outskirts of Volhynian upland is the boundary on the south. The Volhynian Polissia stretches meridionally over $270 \mathrm{~km}$. The landscape diversity of the region is insignificant. Monotonic dunes are diversified with moraine hills, dunes, hills built out of chalk, marl, and limes of Cretaceous period and broad valleys mainly formed on the places of relict valleys.

The region in question lies on the Precambrian Platform. Two large tectonic structures have been distinguished in this area: the Lviv Depression - in the west of the Volhynian Polissia and the elevation of the crystalline foundation - the Ukrainian shield - in the eastern part. In the part of the Lviv Depression, the thickness of the Phanerozoic cover is up to $5 \mathrm{~km}$. This cover is mainly made up of Silurian, Devonian and Carboniferous deposits, on which the Mesozoic deposits have been discordantly accumulated - mainly the Upper Cretaceous. The thickness of the Quaternary cover increase towards the north, where it is usually ca. $40 \mathrm{~m}$ except the river valleys. In the southern part there is a culmination of the Cretaceous deposits and the Quaternary cover is up to $2-10 \mathrm{~m}$. In the eastern part, the Phanerozoic cover is only $60 \mathrm{~m}$, including $10-20 \mathrm{~m}$ of Quaternary formations (Bogucki et al., 2003).

Contemporary relief of the Volhynian Polissia is built by different genetic (glacial, fluvial, paludic, eolic) and age (glaciations of Odra, Warta and Wisła) accumulative processes (Marynych, 1962). The territory is generally inclined in northeastern direction. The relative altitudes vary from $100 \mathrm{~m}$ a.s.I. in the Prypiat River valley to $210 \mathrm{~m}$ a.s.I. on the border of the
Volhynian Upland. Hypsometry differences are within $10 \mathrm{~m}$ but, foremost are 2-7 m. The minimum relative heights are typical for lacustrine-alluvial and outwash plains, maximum relative heights are typical for the culmination of eskers and kames and aeolian forms (Bogucki et al., 2003).

Relict valleys in the Volhynian Polissia are superior zones of outflow of river waters. The Prypiat River valley being the Dnieper tributary and the morphological axis of the Polissia is the biggest relict valley that flows from west to east. The river is supplied with numerous tributaries and especially by right-bank rivers - Turiia, Stokhid, Styr, Horyn and Lva. Within the erosion valleys and sections of the Prypec proglacial valley, the thickness of Quaternary deposits is about $100 \mathrm{~m}$ (Bogucki et al., 2003).

Near-surface moraine deposits were formed during the Dniprovina Glaciation period. Within the Volhynian denuded Morainic Plateau, the thickness of moraine deposits is, on average, 20-30 m. Outwashed sand flatlands with dunes with a maximum height of $5-10 \mathrm{~m}$, have a high prevalence within the area. In Kostopilska Outwash Plain, the thickness of glacifluvial deposits is on average $10-20 \mathrm{~m}$. In the southern part of the area, intensive development of karst processes is observed due to the shallow occurrence of Cretaceous (marl and chalk). The most common forms of surface karst are considered to be sparse karsts of 20-60 m in diameter, their slopes are short $(1-2 \mathrm{~m})$ with an inclination of $10-20^{\circ}$. The depth of forms is 0.5-2 m, flat bottom, boggy (Bogucki et al., 2003). 


\section{MATERIALS AND METHODS}

The set of the informational databases served the initial material. They are:

- archive documentaries with the description of peatbog deposits provided by North-Ukrainian Geological Expedition (Zaleskyi, 1997);

- the materials of the wetland inventory in the natural reserved territories, where their location and contemporary vegetation is given. The materials are provided by the administrations of natural parks;

- soil maps 1:10,000 provided by the administration of soil and tillage stations in Lutsk and Rivne (Veremejenko, 2005; Koloshko, 2007);

- geological maps 1:50,000 with the distribution of the separate lithological groups of deposits on the surface (Burov, 2000);

- SRTM the Digital Elevation Model (USGS, 2005);

- GIS database of topographic objects corresponding to the topographic map in scale of 1:50,000;

- climate maps in a scale of 1:200,000;

- map of unit surface runoff in scale of 1:200,000.

The mentioned above informational resources were processed, unified, and systematised in the form of GIS of the Volhynian Polissia wetlands in the scale of 1:50,000. The database does not include small marshes with the area less than 1 hectare since these objects were not documented.

Given the different specification of data in regards to the type of organic deposits and the need for the integration of information, a rather simple division of wetlands on peatlands (fens, poor fens, raised bogs) and marshes (alluvial mineral marshes, periodic moistlands, telmatic organic marshes). The type of organic deposits is the primary criteria according to which peat and non-peat deposits are distinguished.

The information about peat bogs with existing documentation was supplemented with the data about genetic type of peat bogs, the volume of deposits, the level of peat dissolution, type of underlying rocks.

Boundaries of nature reserved territories and river basins, hydro-melioration networks, the documented sites of peat deposits served other supplementary data.

In the proposed classification of the Volhynian Polissia wetlands, three characteristics of geomorphic-hydrologic conditions of the wetlands were used:

- geomorphic settings;

- type of substrate;

- origin of water.

The geomorphological location was determined on the basis of a detailed geological map based on the lithogenetic type of surface deposits and SRTM the Digital Elevation Model. Typization of relief forms is fulfilled on the basis of the classification principles introduced by Zgorzelski (1988).

Type of substrate wetlands has been defined on the basis of a soil map taking into account the international soil classification system (Soil Taxonomy, 1999). Based on soil type, wetlands have been classified into four groups:

- peatland - widespread peat soils - fibric, hemic and episapric (soils formed out of hydrophilic plants in the process of paludification in the conditions of excessive humidification);

- telmatic organic marsh - widespread limnic soils (formed out of underwater deposits- gyttja, silt);

- alluvial mineral marsh - widespread alluvial sediment soil;

- periodic moistland - widespread folisols (formed in the well-drained conditions with the dominance of aerobiosis), black earth and murshic soils (formed out of different organic deposits in the process of aerobic transformation of organic matter).

The hydrological type of wetlands has been determined on the basis of the criteria set out in Table 2 .

A statistical analysis was used to evaluate the dynamics of groundwater levels in the wetland. The basis of the analysis was a set of data from the period 2005-2012, which provided more than 8,700 observations regarding 21 observation points located in the wetlands. Statistical analysis of observational data is the most frequently used method to determine the range of seasonal, annual and long-term changes in groundwater level (Krogulec et al., 2015, 2016).

A factor analysis was used to assess the spatial dependencies between elements describing the environmental conditioning of land bogging processes (Krogulec et al., 2016). In order to identify the most important factors and to group them according to the significance of the impact, principal component analysis (PCA) was carried out using the Statistica 10.0 software. The algorithm of the programme is based on the analysis of dependencies between the indices of the process. As the result, the indices are united into groups. Next calculating procedures on the basis of statistical methods are to detect the factors that influence on the generation of groups.

The application of factor analysis enables to assess statistical significance of every given factor of the territory marshiness. The specific value in general dispersion of indices served the significance indicator. While building the range of factors according to their significance, fraction in the general dispersion is taken into account. The bigger the fraction the more significant the factor is.

Hydrological types of wetlands depending on the source and water supply system

\begin{tabular}{|c|c|c|c|}
\hline \multirow{2}{*}{ Type of wetlands } & \multicolumn{3}{|c|}{ Parameter used } \\
\hline & Origin of water & recharge system & Type of substrate \\
\hline Soligenic & groundwater & spring, seepage, outflow & $\begin{array}{c}\text { organic-carbonate sequences of deposit, } \\
\text { spring peat }\end{array}$ \\
\hline Topogenic & groundwater & $\begin{array}{l}\text { wetland as a result of shallow } \\
\text { occurrence of the groundwater level }\end{array}$ & $\begin{array}{c}\text { peat, folisols, black earth and murshic } \\
\text { soils }\end{array}$ \\
\hline Ombrogenic & precipitation & surface runoff, precipitation infiltration & limnic and peat soils \\
\hline Fluviogenic & river water & river flooding & alluvial sediment soil \\
\hline
\end{tabular}




\section{RESULTS}

\section{NATURAL CONDITIONS AND SPATIAL DIFFERENCES OF WETLANDS} OF THE VOLHYNIAN POLISSIA

The wetland area in the Volhynian Polissia is $6,327.43 \mathrm{~km}^{2}$. It includes wetlands with the area larger than 1 hectare. The level of waterlogging in the Volhynian Polissia reaches $21.3 \%$, and the level of peat formation is $9 \%$ that is in five times more than the average level for the country $-1.7 \%$ (Lappalainen, 1996). More than half $(56.6 \%)$ of wetlands are periodical non-peat bogs. Peatlands are found on the territory with the area of $2,744.02 \mathrm{~km}^{2}$ covering $9.2 \%$ of the whole Volhynian Polissia. Fens with the area of $1,921 \mathrm{~km}^{2}(70 \%)$ are dominant. The area of raised bogs and poor fens is $823 \mathrm{~km}^{2}(30 \%) .75 \%$ of all the raised bogs and poor fens of Ukraine are located in the Volhynian Polissia.

Due to the continuation of the Volhynian Polissia region in Poland, it is important to compare the spatial diversity of the wetlands of the discussed territory of Poland and Ukraine. For the Polissia region within Poland, a large number of wetlands mainly various types of peat bogs, with a significant share of raised bogs are characteristic. Among the raised bogs there are also rare carbonate bogs (Oświecimska-Piasko et al., 2009). Due to the lack of numerical data for Polissia within Poland, the data for the old glacial zone were used for comparison. In the Polish old glacial zone, wetlands occur on as much as $19 \%$ of the area (2 159,000 ha), which is associated with numerous occurrence of large, flat-bottomed, valleys or occurrence of flooded areas within the valley network. In the majority (15\%) they are non -peat wetlands, mainly alluvial mineral marshes and telmatic organic marshes. The bogging of the Polish old glacial zone is 4\% (Oświecimska-Piasko et al., 2009).

The features of location and peculiarities of differences of the Volhynian Polissia wetlands are reflected in the geomorphological zoning. Five geomorphological regions are distinguished here (Steciuk, 2010). They are Gornoprypiatska Accumulation Plain, Volhynian denuded Morainic Plateau, Sarnenska Ice Marginal Valley, Klesiwska denuded Morainic Plateau and Kostopilska Outwash Plain (Fig.1).

The Gornoprypiatska Accumulation Plain (the Prypiat relict valley) and Sarnenska Ice Marginal Valley with the areas of 33.9 and $29.1 \%$ respectively are the most waterlogged. Half of these areas are covered with peatlands (Table 3 ).

Peatlands are distributed in ice marginal valleys the most. They are mostly the lowland ones with the volume of peat deposits of $4 \mathrm{~m}$. On the territory of relict valleys, there are three regions of wetland concentration (Fig. 2):

- Ice Marginal Valleys of Styr-Slovechno - since the times of the Odra Glaciation;
- Ice Marginal Valleys of Turia - since the times of the Odra Glaciation;

- Ice Marginal Valleys of Prypiat - since the times of the Warta Glaciation (the largest peat bog - Prypiatske 35,000 hectares).

Ice marginal valleys are distinguished for the broad shape $(5-10 \mathrm{~km})$, flat bottom, mostly filled up with the fens Waterlogging of the mentioned valleys varies within $30-85 \%$. The high level of waterlogging is the result of favourable geomorphological conditions. The valley is supplied by the slope surface and underground flows from the neighbouring moraine and sandr landscapes. The flat-bottomed character of the valley contributes to stagnation and the complicated water flow that triggers waterlogging.

The peatlands have been also often developed in the lacustrine-accumulation plains during the Wisła Glaciation on the outskirts of the Vezhytsia (the largest peatlands - Kreminne 40,000 hectares) and Kamin Kashyrskyi localities.

Two thirds of raised bogs and poor fens with the total area larger than half $(55 \%)$ of all the peatlands in the area are located in the Volhynian denuded Morainic Plateau. The majority of peatlands have a preserved mound with the height of $1 \mathrm{~m}$. Small (less than 5 hectares), but at the same time deep peatlands $(2-5 m-58 \%$ of peatlands, more than $5 m-23 \%$ of peatlands) are dominant. The column of low-penetrating moraine deposits serves the underlying rocks. Peatlands with the biggest volume (up to $8 \mathrm{~m}$ ) and the bottom covered with gyttja are sporadically distributed in subglacial depression.

The most appropriate geomorphological conditions for wetlands are detected in the Kostopilska Outwash Plain, where lacustrine and peatlands complexes are dominant. The downward direction of the peat genesis process is characteristic of the complexes. The age of lakes of the Volhynian Polissia is referred to the final stage of the North Polish glaciation (Bogucki, 2005). Small and shallow wetlands $(0.5-1.75 \mathrm{~m})$ in local depressions are typical for sandr plains. The volume of clayey sands on fluvioglacial anisomerous sands with the depth of 10-25 $\mathrm{m}$ serves the underlying rocks.

On the border of the Volhynian Polissia and the Volhynian upland, the culmination of limestone deposits of Cretaceous period is found. The volume of quaternary deposits decreases to $2-10 \mathrm{~m}$. The Upper Cretaceous deposits are mostly represented by marl. In some places, they come to the surface that leads to the development of karst forms. Carbonate lowland peatlands are formed in drainless hollows where the limestone and detritus gyttja covers the bottom (Bogucki, 2005). The volume of peat is $3 \mathrm{~m}$, maximum $-8.5 \mathrm{~m}$. It is an absolute lowland peat, mostly with sedge and rush. The peatlands are developed on the carbonate deposits of Upper Cretaceous. Surface deposits of Upper Cretaceous are of small volume and built up by fluvioglacial and aluvial-periglacial deposits.

Wetlands in geomorphological regions of Volhynian Polissia

\begin{tabular}{|l|c|c|c|c|}
\hline \multirow{2}{*}{\multicolumn{1}{c|}{ Geomorphological region }} & \multirow{2}{*}{$\begin{array}{c}\text { Total area } \\
{\left[\mathrm{km}^{2}\right]}\end{array}$} & \multicolumn{3}{c|}{ Participation in the wetlands area [\%] } \\
\cline { 3 - 5 } & 5173.94 & Share of wetlands & Share of peatlands & Marshes \\
\hline Gornoprypiatska Accumulation Plain & 10508.62 & 18.5 & 12.4 & 21.5 \\
\hline Volhynian denuded Morainic Plateau & 3513.11 & 29.1 & 7.3 & 11.2 \\
\hline Sarnenska Ice Marginal Valleys & 3528.12 & 24.6 & 16.1 & 13.9 \\
\hline Klesiwska denuded Morainic Plateau & 7012.11 & 10.5 & 3.3 & 7.6 \\
\hline Kostopilska Outwash Plain & 29735.90 & 21.3 & 9.2 & 12.1 \\
\hline Volhynian Polissia & & & & \\
\hline
\end{tabular}




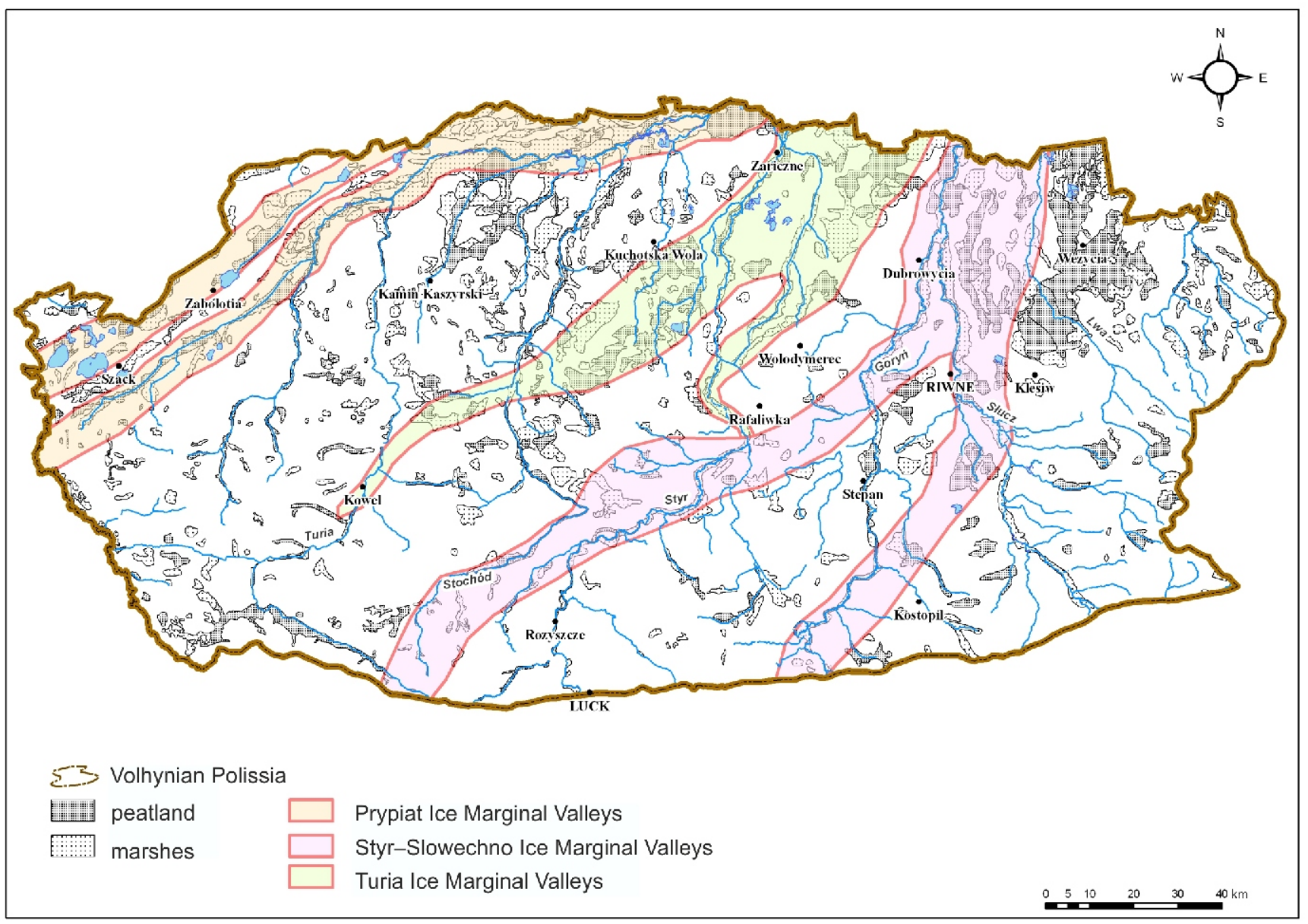

Fig. 2. General Ice Marginal Valleys the Volhynian Polissia (after Marynych and Shyshchenko, 2006)

The spring peatlands formed in paralimnic and paludic environments are locally distributed on the territory. Biogenic deposits in paraliminic conditions are represented by rhythmic sequence of travertine and silt deposits that are accumulated in small spring basins of karst waters. Here, paludic environment is developed in the result of a gradual termination of the karst waters outflow. In such conditions, peat contaminated by calcium carbonate is formed.

In the Volhynian Polissia, precipitation sums insufficiently exceed the evapotranspiration rate (Kynal and Krogulec, 2009). The location of most of the wetlands in concave relief forms points to the dominant influence of geological, geomorphological and hydrogeological conditions on the development of hydrogenic complexes.

To determine the main factors of the Volhynian Polissia development, factor analysis is used. Water body area served the elementary spatial unit of factor analysis. 406 water body area is located in the research area. Quantitative measurement parameters that describe natural conditions of the wetland development served the initial information for factor analysis. The involved data can be divided into three blocks.

The first block consists of hydrologic and climatic parameters that determine the water balance in the region:

- norm of annual precipitation sums on the basis average weighted value within the region [mm];

- norm of annual maximal potential evapotranspiration on the basis of average weighted value in the region [mm];
- average multiannual surface discharge volume on the basis of average weighted value within the region $\left[\mathrm{l} / \mathrm{s} \times \mathrm{km}^{2}\right]$.

Geological, geomorphological and hydrogeological parameters that describe waterlogging conditions constitute the second block:

- maximal depth of vertical relief dissection [m];

- integral level of horizontal and vertical relief dissection on the basis of relief dissection index $\left[\mathrm{km} / \mathrm{km}^{2}\right]$;

- water permeability of dominant surface deposits on the basis of the filtration [m/day];

- groundwater level on the basis average weighted value within the region $[\mathrm{m}]$;

- density of springs [amount $/ \mathrm{km}^{2}$ ].

Main morphometric parameters of water body area constitute the third block:

- geographical position on the basis of coordinates of its average weighted centre;

- average altitude of surface [m];

- density of river network $\left[\mathrm{km} / \mathrm{km}^{2}\right]$;

- lakes on the basis the coefficient of lakes [\%];

Marshiness of the territory as a dependent characteristic is determined with the coefficient of marshiness.

The selected parameters have been calculated for everyone 406 water body area. Table 4 presents the range of variability of parameters included in the factor analysis.

The matrix of correlation coefficients that is the basis for factor analysis is given in the Table 5 . 
Range of variability of parameters included in the factor analysis

\begin{tabular}{|l|c|c|}
\hline \multicolumn{1}{|c|}{ Group of parameters } & Type of parameter & Range of variability \\
\hline \multirow{3}{*}{ Hydrological and climatic } & average multiannual precipitation sum & $510-720 \mathrm{~mm}$ \\
\cline { 2 - 3 } & average multiannual evapotranspiration & $430-540 \mathrm{~mm}$ \\
\cline { 2 - 3 } & average multiannual discharge & $2.2-4.5 \mathrm{l} / \mathrm{s} \times \mathrm{km} \mathrm{m}^{2}$ \\
\hline \multirow{3}{*}{$\begin{array}{l}\text { Geological, } \\
\text { geomorphological and } \\
\text { hydrogeological }\end{array}$} & maximum depth of vertical relief dissection & $0.3-25 \mathrm{~m}$ \\
\cline { 2 - 3 } & integrated level of horizontal and vertical relief dissection & $0.2-0.8 \mathrm{~km} / \mathrm{km}^{2}$ \\
\cline { 2 - 3 } & water permeability of dominant surface deposits & $0.1-75 \mathrm{~m} / \mathrm{day}$ \\
\cline { 2 - 3 } & groundwater level & $0.2-18.7 \mathrm{~m}$ \\
\hline \multirow{3}{*}{ Morphometric } & density of springs & $17 \mathrm{amount} / \mathrm{km}^{2}$ \\
\cline { 2 - 3 } & average altitude of surface & $0.1-1-1 \mathrm{~km} / \mathrm{km}^{2}$ \\
\cline { 2 - 3 } & density of river network & $0.1-73 \%$ \\
\hline
\end{tabular}

The matrix of main factors of marshiness of water body area

\begin{tabular}{|l|r|r|r|}
\hline \multicolumn{1}{|c|}{ Parameters } & \multicolumn{3}{c|}{ Factors } \\
\cline { 2 - 4 } & \multicolumn{1}{c|}{1} & \multicolumn{1}{c|}{2} & \multicolumn{1}{c|}{3} \\
\hline Geographical latitude of geometrical centre of the region & 0.69 & -0.43 & -0.46 \\
\hline Geographical longitude of geometrical centre of the region & -0.57 & -0.05 & -0.32 \\
\hline Average altitude of surface & 0.10 & -0.10 & -0.33 \\
\hline Coefficient of the density of the river network & 0.08 & 0.58 & 0.61 \\
\hline Coefficient of lakes & 0.35 & 0.73 & -0.53 \\
\hline Maximum depth of vertical relief dissection & 0.03 & 0.21 & 0.16 \\
\hline Integrated level of horizontal and vertical relief dissection & 0.06 & 0.71 & 0.91 \\
\hline Water permeability of dominant surface deposits & 0.00 & -0.10 & 0.30 \\
\hline Groundwater level & -0.33 & 0.81 & 0.26 \\
\hline Density of springs & 0.41 & 0.91 & 0.29 \\
\hline Average multiannual precipitation sum & 0.71 & 0.44 & 0.15 \\
\hline Average multiannual evapotranspiration & -0.65 & 0.03 & -0.11 \\
\hline Average multiannual discharge & 0.51 & -0.26 & -0.32 \\
\hline Marshiness of the region & 0.59 & 0.67 & 0.48 \\
\hline Fraction in general dispersion & 0.25 & 0.42 & 0.33 \\
\hline
\end{tabular}

Table 5 shows that the first block of factors explains $25 \%$ of general spatial variability of marshiness in Polissia. The second block explains $42 \%$, and the third one $-33 \%$.

The first factor highlights climatic conditions of the territory. Marshiness of the territory is related to the value of annual sum of precipitation that decreases in the southern direction. Reverse connection between climatic characteristics and marshiness is characteristic of the annual maximal potential evapotranspiration the value of which increases in the southern direction. The first factor explains $25 \%$ of total dispersion.

The second factor reflects the dependence of the territory marshiness on the geological, geomorphological, and hydrogeological conditions that in sum determine the distribution and development of marshes. They are the level of horizontal and relief dissection, the depth of the first aquifer position and the outlets of underground waters in the form of springs. The territory marshiness is the most closely related to hydrogeological characteristics. Here, the release of pressure underground waters is more significant than the depth of the first aquifer position. Another valuable predictor determining marshiness is the level of horizontal and vertical relief dissection (direct connection). Close direct connection between lakes and the territory marshiness witness of post- genesis of marshes. The second factor characterises $42 \%$ of total dispersion.

The third factor depicts the close connection of main morphometric indices - integral relief dissection level and the density of river network and the reverse relation of these characteristics with lakes. Hydrographical network sufficiently determines the wetland distribution. The fraction of the third factor in total dispersion is $33 \%$.

The results show that marshiness in the Volhynian Polissia is mostly determined by the peculiarities of geological, geomorphological and hydrogeological conditions. The influence of climatic factor is mediated and third in importance.

\section{CLASSIFICATION OF WETLANDS OF THE VOLHYNIAN POLISSIA}

The documentation analysis of peat deposits including geological and stratigraphic profiles of peats showed that peatlands are located in depressions of different genesis and geological structure. Depending on the relief form of wetland depression, 7 groups of wetlands on the basis of morphogenetic structure of depressions in the Volhynian Polissia: ice marginal valleys, 
The wetland division of the Volhynian Polissia according to geomorphological conditions

\begin{tabular}{|l|c|c|c|c|c|}
\hline \multirow{2}{*}{$\begin{array}{c}\text { Geomorphological conditions } \\
\text { occurrence of wetlands }\end{array}$} & \multirow{2}{*}{$\begin{array}{c}\text { Total area of wetlands, } \\
\text { ha [\%] }\end{array}$} & $\begin{array}{c}\text { Area of marshes } \\
\text { [ha] }\end{array}$ & \multicolumn{3}{|c|}{ Area of peatlands [ha] } \\
\cline { 4 - 6 } & $84784(13.4)$ & 81362 & 63594 & 17170 & 46424 \\
\hline Ice marginal valleys & $40235(6.4)$ & 0 & 25192 & 23867 & 1325 \\
\hline Meltout depressions & $118324(18.7)$ & 39581 & 63700 & 20425 & 43275 \\
\hline $\begin{array}{l}\text { Shallow depressions without } \\
\text { Outlets on the morainic plateau }\end{array}$ & $18350(2.9)$ & 0 & 18350 & 1835 & 16515 \\
\hline Channel depressions & $71376(11.3)$ & 0 & 56333 & 15309 & 41024 \\
\hline Intra-dune depressions & $24677(3.9)$ & 8400 & 16277 & 977 & 15300 \\
\hline Sinkholes and headwater areas & $274997(43.4)$ & 228998 & 30956 & 2719 & 28237 \\
\hline River valleys & $632743(100)$ & 358341 & 274402 & 82302 & 192100 \\
\hline Volhynian Polissia & & & & Raind \\
\hline
\end{tabular}

meltout depressions, shallow depressions without outlets the morainic plateau, channels depressions, intra-dune depressions, sinkholes and headwater areas and the wetland areas in these morphogenetic structures are represented in Table 6.

The relation between morphogenetic peculiarities of wetland depressions and wetland type is argued. The variety and diametrical zonality in the distribution caused by microrelief and differences of hydrological supply of wetlands are characteristic of the river valley bogs. One specific type of wetlands is dominant in the rest of morphogenetic structures.

According to the accumulation type of organic deposits in the Volhynian Polissia, four types of peatlands are distinguished: post-lacustrine, paludificational, riverside and spring. The structure of post-lacustrine peatlands of the Volhynian Polissia imply that in the process of peat accumulation in lakes, first, the lowland fens was developed that, later, in the result of succession was transformed in the raised bogs one. Rarely, in the region, in the process of peat genesis of dystrophic lakes, poor fens, or sometimes the raised bogs ones were formed. Post-lacustrine peatlands are the most numerous in the region (almost $70 \%$ ). In the history of development of post-lacustrine peatlands, the particular sequence of succession is noticed. It is reflected in the profile of deposits: on the bottom - the detritus and limestone gyttja, above on which - sedge, sedge and moss, and alder peatbogs. The latter points to the variability of the water inflow conditions. The alder peatbog is characteristic of small peatlands.

In paludificational peatlands, organic deposits are accumulated right above the mineral foundation. The marshiness process is possible because of the surface position of groundwaters. The first stage - gley and juvenile - occurs in the case of anaerobic conditions in mineral soil that is caused by the high level of groundwaters. It is manifested in the gley formation of the soil profile. The processes of gley formation in the conditions of stable waterlogging transform into the wetland soil genesis processes. Due to the latter, gley mineral soils turn into peat and gley with the peat volume up to $30 \mathrm{~cm}$ that significantly influences phytocenotical features of the ecosystems. In the case, mesophilic types are ejected, instead, hygrophytes and hydrophytes appear. In the decay process of bog phytocenoses, peat is accumulated. The peat accumulation with the volume of $30 \mathrm{~cm}$ determines the boundary between the gley-juvenile and eutrophic stages of the peatlands development. The next stages are the same as the post-lacustrine type of wetland genesis. Instead, this type of peatlands remains eutrophic in the Polissia while not turning to oligotrophic stage.
In the profiles of riverside wetlands in former river beds, silt is the typical layer, and peat deposits are rare and two-layered. In the lower part, alder or rush peat is located. The upper part is built up with sedge cane peat, sometimes the alder one. Humus is the main component of silt with admixtures of colloidal mineral particles that altogether form organic and mineral complexes. The silt volume reaches maximally 1 metre, but mainly is within $0.2-0.25 \mathrm{~m}$.

The spring wetlands in karst massifs in the Volhynian Polissia are developed in the form of swamps. Their profile is represented by a thin-rhythmical sequence of travertine, sedge, and rush peat. Top-shaped spring peat bogs sometimes have place too.

In the area of research, all hydrological types of wetlands are widespread, including:

1. Ombrogenic wetlands that are located in drainless hollows in the conditions of good isolation from groundwaters. They are formed due to the surface flow stagnation and the accumulation of precipitation on the waterproof foundation of surface deposits. Ombrogenic wetlands are characteristic of landscapes of the wavy-bottomed or hilly final moraine and lacustrine-accumulation plains.

2. Topogenic wetlands are formed in the places of shallow position of groundwaters with an insignificant slope that provides almost stagnant water regime. The wetlands have place in sandr landscapes and develop in total dependence on groundwaters.

3. Soligenic wetlands - spring and running wetlands developed in the places of outlets of groundwaters. The wetlands are formed in the bank parts of river valleys in the places of numerous outlets of groundwaters and in karst massifs. Pressure soligenic bogs are related to the erosion and karst structures.

4. Fluviogenic wetlands are typical for wide and flat-bottomed river valleys with the distinctive phase of durable stagnation of waters in flood plain. Old-river beds are the main centres of fluviogenic wetland genesis determined with regular waterlogging of flood plain by flood waters and discharge of groundwaters.

Every hydrological type has its own features of water regime. The analysis of annual changes of the groundwater level of wetland was performed on the basis of 21 wetlands:

1. Ombrogenic (5 observation points), in the supply of which groundwater are not present, located in drainless hollow. 
The depth of the groundwater levels in wetlands of different hydrological types

\begin{tabular}{|l|c|c|c|c|c|}
\hline \multirow{2}{*}{ Hydrological type of wetland } & \multicolumn{3}{|c|}{$\begin{array}{c}\text { The main statistical characteristics of the depth (m) of the groundwater levels } \\
\text { (average for the period 2005-2012) }\end{array}$} \\
\cline { 2 - 6 } & $\begin{array}{c}\text { average (geometrical) } \\
\text { annual depth }\end{array}$ & annual range & $\begin{array}{c}\text { maximal } \\
\text { depth }\end{array}$ & $\begin{array}{c}\text { minimal } \\
\text { depth }\end{array}$ & $\begin{array}{c}\text { variation } \\
\text { coefficient }\end{array}$ \\
\hline Ombrogenic & 0.06 & 0.34 & 0.23 & $+0.11^{*}$ & 0.025 \\
\hline Topogenic & 0.15 & 0.33 & 0.32 & +0.01 & 0.014 \\
\hline Soligenic & 0.10 & 0.31 & 0.26 & +0.05 & 0.007 \\
\hline Fluviogenic & 0.17 & 0.60 & 0.50 & +0.10 & 0.056 \\
\hline
\end{tabular}

${ }^{*}-(+)$ means the outlets of groundwaters on the surface

2. Topogenic (5 observation points), with hydraulic connection with non-pressure groundwater.

3. Soligenic (5 observation points), influenced by pressure groundwater and located in relict valleys.

4. Fluviogenic (6 observation points), located in the zone of river waters in flood plain.

Monitoring data of Geological Survey of Ukraine and North-Ukrainian Geological Expedition are the input material (http://www.geo.gov.ua). The observation points have the sufficiently long and continuous observational time series (2005-2012) with the frequency of measurements at least once per week. All the basic results from all of the observation points are presented in Table 7.

The highest average annual groundwater level in the period 2005-2012 at the level of $0.06 \mathrm{~m}$ below the earth's surface remained in the ombrogenic wetlands. The deepest groundwater table was maintained in the fluviogenic wetlands. The average annual level of groundwater in this period was $0.17 \mathrm{~m}$ below ground surface.

The average annual level of groundwater in this period fluctuated in the wetlands:

- ombrogenic - from 0.01 m below ground surface (b.g.s.) in 2010 to 0.14 mbgs in 2005;

- topogenic - from 0,08 m b.g.s. in 2011 to $0.23 \mathrm{~m}$ b.g.s. in 2006;

- soligenic - from 0.03 m b.g.s. in 2010 to $0.17 \mathrm{~m}$ b.g.s. in 2006;

- fluviogenic - from 0,08 m b.g.s. in 2010 to $0.38 \mathrm{~m}$ b.g.s. in 2006.

Similar trends in the annual average groundwater level in the wetland areas were observed in central Poland (Krogulec and Zabłocki, 2015).

Table 7 shows the difference in quantitative parameters of water regime of wetland depending on the hydrological type.

The characteristic feature of seasonal dynamics of water levels in ombrogenic wetlands is a rapid increase and gradual decrease that is related to the small area of catchment and less time for water running. As a result, more rapid reaction of water level on precipitation in the wetlands occurs. Due to the dominance of an insufficiently decayed moss peat in the wetland structure, the wetland is able to accumulate and hold a big amount of stagnant waters the volume of which reach $90 \%$ of the wetland depression volume (Maslov, 2009). Consequently, the level of groundwaters of the ombrogenic wetland in the dry period gradually decreases. The close relation between the level of groundwaters and precipitation, as well as air temperature and humidity that determine the evapotranspiration value, is detected in ombrogenic wetlands. Average annual depths of the groundwaters position are in close relation with the annual precipitation sum. The coefficient correlation calculated for the ombrogenic wetland is within 0.82 . Summer decrease of groundwaters is closely related to the evapotranspiration value: the correlation coefficient is 0.78 .

Water regime of soligenic and topogenic wetland is rather stable. Hydrogeological factor is the main regime-forming factor. Diurnal fluctuations of the groundwater position in wetlands in the conditions of the supply by pressure groundwaters are minimal $-0.01-0.02 \mathrm{~m}$ per day. Wetlands dependent on groundwaters have the longest (2.5-3 months) phase of the spring period of the water level increase in comparison to the other wetland types. It is caused by the bigger inertia of groundwater. In water regime of non-pressure wetlands, the spring-autumn and winter period of the water level slight decrease is observed.

The main feature of water regime of fluviogenic wetlands is the significant dependence on the river water regime and the direct influence of high waters. The wetland water regime follows the phases of the river water regime. Alongside, more durable intervals of the high waters stagnation are detected. For instance, if the duration of high waters on the river is 1.5-2 months, then this phase on the flood plain wetland lasts for almost 2.5 months. In this wetland, maximal levels reached $0.34 \mathrm{~m}$ above the ground surface. In the mean water time, the groundwater level was $0.50 \mathrm{~m}$. It was minimal for the system. Water regime of fluviogenic wetlands is characteristic of the biggest range of fluctuations (in the investigated wetland, it reaches $0.60 \mathrm{~m}$ ) and variability (coefficient of variation is 0.056 ) of the groundwater level.

Consequently, the stability of water regime of wetlands is determined by multi-variance of the supply sources, and is strengthened by the increase of groundwater discharge. Water regime of soligenic wetlands follows the character of functioning of the hydrgeoological system within which it exists. Water regime of ombrogenic wetlands is totally controlled by meteorological rhythms and is distinguished for the apparent seasonality. The variety of the supply sources of fluviogenic wetlands contributes to the most complicated manifestation and the largest dynamics of the level changes and the directions of water flow in wetlands.

\section{CONCLUSIONS}

The review of the wetland definition underlines that for a given area to be considered wetland, it must meet three criteria at the same time: (1) permanent or periodical waterlogging; (2) the dominance of hydrophilic vegetation; (3) hydromorphic type of the soil-genesis process and the peat accumulation.

The proposed wetlands classification of Volhynian Polissia aims to take into account the main environmental conditions for 
the development of wetlands and includes geomorphological, soil and hydrological criteria. This classification includes similar assumptions to the classification scheme proposed by Okruszko (1992).

The developed GIS of the Volhynian Polissia wetlands in the scale of 1:50,000 made it possible to determine the spatial diversity of the wetlands in the research area. The level of development of wetlands in the Volhynian Polissia that cover $9.2 \%$. The type and location of wetlands in the region depend on geological, geomorphological and hydrogeological conditions. Geomorphological zoning reflects the features of distribution and the peculiarities of the wetland variety in the Volhynian Polissia. Four types of post-glacial relief are dominant in the region: moraine uplands, relict valleys, and lacustrine-accumulation and sandr plains.

Two thirds of raised bogs and poor fens in the region are located in moraine uplands. They are non-uniformly distributed in depressions of different genesis. Soligenic type of supply is characteristic of the majority of wetlands. The largest peatlands, mostly fens, are located in relict valleys (Styr-Slovechno, Turiia, Prypiat). Wetlands of the soligenic supply type are developed on the sides of valleys. Wetlands of fluviogenic type are concentrated in the old-river beds. Peatlands in the lacustrine-accumulation plains (on the outskirts of the Vezhytsia and Kamin Kashyrskyi localities) are related to drainless depressions and are considered to have ombrogenic type of supply. Peatlands of the topogenic type of supply are formed in shallow concave relief forms in sandr plains. Other marshes are related to river valleys and have fluviogenic type of supply. On the southern rim of the Volhynia Polissia, in carboniferous karstic basins, carbonate peatbogs with a soligenic type of alimentation have developed.

Statistical analysis of the point monitoring data enabled a determination of the scope of the groundwater level changes in the period 2005-2012, and in the annual and seasonal periods.
It was found that in 2005-2006 and 2010-2011 there were the lowest and highest levels of groundwater respectively. The range of changes ranged from $0.01 \mathrm{~m}$ b.g.s. (2010) to 0.14 m b.g.s. (2005) in ombrogenic wetlands; from $0.08 \mathrm{~m}$ b.g.s. (2011) to $0.23 \mathrm{~m}$ b.g.s. (2006) in topogenic wetlands; from 0.03 $\mathrm{m}$ b.g.s. (2010) to $0.17 \mathrm{~m}$ b.g.s. (2006) in soligenic wetlands and from $0.08 \mathrm{~m}$ b.g.s. (2010) to $0.38 \mathrm{~m}$ b.g.s. (2006) in fluviogenic wetlands.

Maximal ranges of diurnal changes are observed in the vegetation period, when transpiration and evapotranspiration are the leading processes in the discharge part of water balance. Seasonal changes are determined by the type of the wetland supply. The most apparent seasonal cycles are detected in ombrogenic wetlands. The highest annual stability of water regime is typical for soligenic and topogenic wetlands. The diversity of supply sources of fluviogenic wetlands causes the most complicated character and the biggest dynamics of level changes and water flow directions in wetlands.

Results of the factor analysis indicate that in the Volhynian Polissia the marshiness of the area is to a greater extent determined by the peculiarity of the geological and geomorphological conditions. The climatic factor has an indirect and tertiary impact. Presence of peatbogs within the river valleys is mostly related to the presence of a dense river network and a shallow depth of the groundwater table while presence of peatbogs within the wavy moraine plains is determined by the occurrence of numerous outflow depressions and the presence of sources. On sandbank plains, presence of peatbogs is associated with lithology of subsurface sediments.

Acknowledgments. Author wish to thank by Prof. E. Krogulec and anonymous reviewers for their very constructive suggestions and comments.

\section{REFERENCES}

Bachurina, G., 1964. Torfovi bolota Ukrayinskoho Polissya (in Ukrainian). Naukova dumka, Kyiv.

Balashov, L., Kucheryava, L., 1974. Olihotrofni bolota Poliskoho derzhavnoho zapovidnyka (in Ukrainian). Ukrayins'kyy botanichnyy zhurnal, 31: 83-88.

Bertrand, G., Goldscheider, N., Gobat, J.M., Hunkeler, D., 2012 Review: from multi-scale conceptualization to a classification system for inland groundwater-dependent ecosystems. Hydrogeology Journal, 20: 5-25.

Bogucki, A., Zaleski, I., Karpenko, N., Kowalczuk, I., Krawczuk, J., 2003. Goelogic-geomorphologic evolution of the nort-western part of the Volhynia Polesie. Acta Agrophysica, 1: 217-232.

Boguckij, A., 2005. Rozważania nad morfogenezą Polesia (in Polish). Materiały XIII ukraińsko-polskiego seminarium. Centrum wydawnicze Narodowego Uniwersytetu im. Iwana Franko, Lwów: 211-219.

Bradis, E.M., Bachurina, G.F., 1969. Bolota URSR (in Ukrainian). Naukova dumka, Kyiv.

Brinson, M., 1993. A hydrogeomorphic classification for wetlands. Final report, technical report WRP-DE-4. US Army Corps of Engineers, Washington DC

Burov, V., 2000. Heolohichna karta Volyns'koyi oblasti 1:50 000 (in Ukrainian). Pivnichnokoreys'ka heolohichna ekspedytsia, Luck.

Cowardin, L.M., Carter, V., Golet, F.C., LaRoe, E.T., 1979. Classification of wetlands and deepwater habitats of the United States.
U.S. Department of the Interior, Fish and Wildlife Service, Washington, D.C., Jamestown.

Davies, R.B., Anderson, D.S., 2001. Classification and distribution of freshwater peatlands in Maine. Northeast Naturalist, 8: 1-50.

Dembek, W., 2000. Wybrane aspekty zróżnicowania torfowisk w młodo- i staroglacjalnych krajobrazach Polski wschodniej (in Polish). IMUZ, Falenty.

Dembek, W., Oświt, J., 1992. Rozpoznawanie warunków hydrologicznego zasilania siedlisk mokradłowych (in Polish). Biblioteczka Wiadomości IMUZ, 79: 15-37.

Dokuchaev, V., 1949. Po voprosu ob osushenyy bolot voobshche i, $\checkmark$ chastnosty, ob osushenyy bolot Polesya (in Russian). Raboty v oblasty geology, Moskov.

Gilvear, D.J., Mclnnes, R.J., 1994. Wetland hydrological vulnerability and the use of classification procedures: a Scottish case study. Journal of Environmental Management, 42: 403-414.

Grygora, I., Vorobyov, E., Solomakha, V., 2005. Lisovi bolota Ukrayinskoho Polissya (pokhodzhennya, dynamika, klasyfikatsiya) (in Ukrainian). Fitosotsiotsentr, Kyiv.

Haslam, S.M., 2003. Understanding Wetlands. Fen, bog and marsh. Taylor and Francis, Hardback.

Ilnicki, P., 2002. Torfowiska i torf (in Polish). Wydawnictwa Akademii Rolniczej, Poznań.

Ilyin, L., 2004. Ozerno-bolotni kompleksy Volyni (in Ukrainian) Hydrologia, Hydrochemia, Hydroekologia, 6: 314-319. 
Ilyina, O., 2004. Bolota i zabolocheni dilyanky Volynskoyi oblasti: Dovidnyk (in Ukrainian). Teren, Luck.

Ilyina, O., 2005. Ekologo-geografichnyj analiz bolit Volynskoyi oblasti (in Ukrainian). L'vivs'kyy natsional'nyy universytet, Lviv.

Jermaczek, A., Wołejko, L., Misztal, K., 2009. Poradnik ochrony mokradeł w górach (in Polish). Wydawnictwo Klubu Przyrodników, Świebodzin.

Koloshko, L., 2007. Karta gruntu Volyns'koyi oblasti 1:10 000. Materialy Upravlinnya hruntovo-sil's'kohospodars'koyi stantsiyi v Lucku (in Ukrainian). Hruntovo-sil's'kohospodars'ka stantsia, Luck.

Krogulec, E., Zabłocki, S., 2015. Relationship between the environmental and hydrogeological elements characterizing groundwater-dependent ecosystems in central Poland. Hydrogeology Journal, 23: 1587-1602.

Krogulec, E., Zabłocki, S., Sawicka, K., 2016. Changes in groundwater regime during vegetation period in Groundwater Dependent Ecosystems. Acta Geologica Polonica, 66: 525-540.

Kulczyński, S., 1939a. Torfowiska Polesia (in Polish), T. 1. Wyd Uniwersytetu Jagiellońskiego, Kraków.

Kulczyński, S., 1939b. Torfowiska Polesia (in Polish), T. 2. Wyd. Uniwersytetu Jagiellońskiego, Kraków.

Kynal, O., Krogulec, E., 2009. Hidroklimatychni osoblyvostyi zvolozennyia terytoryij (in Ukrainian). Moshynski, Kamieniec Podolski.

Lappalainen, E., 1996. Global Peat Resources. Jyska.

Łachacz, A., 2004. Mokradła w krajobrazie - wybrane pojęcia (in Polish). Woda - Środowisko - Obszary Wiejskie, 4, z. 2a: 295-301.

Marynych, O., 1962. Ukrayinske Polissya (in Ukrainian). Wydawnyctwo radians'ka shkola, Kyiv.

Marynych, O.M., Shyshchenko, P.G., 2006. Geografia fizychna Ukrainy (in Ukrainian). Tov-vo "Znannyia", Kyiv.

Maslov, B., 2009. Hydrolohyya Torfyanykh Bolot (in Russian). Wyd., Moskva.

Mitsch, W.J., Gosselink, J.G., 2007. Wetlands. 4th ed., John Wiley and Sons, Hoboken, NJ.

Mitsch, W.J., Gosselink, J.G., Zhang, Li, Anderson, C.J., 2009. Wetland Ecosystems. Wiley and Sons, Hoboken, NJ.

Okruszko, H., 1992. Siedliska hydrogeniczne, ich specyfika i zróżnicowanie (in Polish). Biblioteczka Wiadomości IMUZ, 79 $1-100$.

Okruszko H., Dembek, W., Oświecimska-Piasko, Z., 2001. Geomorfologia a mokradła jako problem naukowy. Woda Środowisko - Obszary Wiejskie, 1, z. specj.: 7-16.

Oświecimska-Piasko, Z., Piórkowski, H., Rycharski, M. Jarzombkowski, F., Jakubowski, W., eds., 2009. Ekosystemy lądowe pozostające $w$ dynamicznych relacjach $z$ wodam podziemnymi i powierzchniowymi dla obszarów dorzeczy w
Polsce. Części I-III (in Polish). TECHMEX S.A., IMUZ, Warszawa (praca niepublikowana).

Pawlaczyk, P., Wołejko, L., Jermaczek, A., Stańko, R., 2001. Poradnik ochrony mokradeł (in Polish). Wydawnictwo Lubuskiego Klubu Przyrodników, Świebodzin: 59-151.

Pawlaczyk, P., Herbichowa, M., Stańko, R., 2005. Ochrona torfowisk bałtyckich (in Polish). Przewodnik dla praktyków, teoretyków i urzędników. Wydawnictwo Lubuskiego Klubu Przyrodników, Świebodzin.

Ramsar Convention Secretariat, 2013. The Ramsar Convention Manual: A Guide to the Convention on Wetlands (Ramsar, Iran, 1971), 6th ed. Ramsar Convention Secretariat, Gland, Switzerland.

Soil Taxonomy, 1999. A basic system of soil classification for making and interpreting soil surveys. Soil Survey Staff. USDA-NRCS. Agric. Handb. 436. US Gov. Printing Office, Washington DC.

Solovey, T. 2013. Osoblyvosti formuvannya i hidroloho-hidrokhimichnyy rezhym bolit $\mathrm{v}$ umovakh posthlyatsialnykh terytoriy Ukrayiny i Polshchi (in Ukrainian). Yurii Fedkovych Chernivtsi National University, Chernivtsi.

Steciuk, V., 2010. Relyief Ukrainy (in Ukrainian). Slovo, Kyiv.

Tanfiliev, G.I., 1895. Bolota i torfianiki Polesia (in Russian ). San Petersburg.

Tobolski, K., 2000. Przewodnik do oznaczania torfów i osadów jeziornych (in Polish). PWN, Warszawa.

USGS, 2005. SRTM DTED. US Geological Survey, URL: http://edc.usgs.gov/products/elevation/ srtmdted.html

Veremejenko, S., 2005. Karta gruntu Rivnets'koyi oblasti 1:10 000 Materialy Upravlinnya hruntovo-sil's'kohospodars'koyi stantsiyi v Rivnomu (in Ukrainian). Hruntovo-sil's'kohospodars'ka stantsia, Rivne.

Westlake, D.F., Kvet, J., Szczepanski, A., 2012. The Production Ecology of Wetlands. Cambridge University Press, Cambridge.

Wheeler, B., Proctor, M., 2000. Ecological gradients, subdivisions and terminology of north-west European mires. Journal of Ecology, 88: 187-203.

Yvanov, K., 1975. Vodoobmen v bolotnykh landshaftakh (in Russian). Hydrometeoyzdat, San Petersburg.

Zaleskyi, I., 1997. Heomorfolohichna karta Volyns'koyi oblasti 1:100 000 (in Ukrainian). Pivnichnokoreys'ka heolohichna ekspedytsia, Luck.

Zerov, D.K., 1938. Bolota URSR. Roslynnist i stratygrafia (in Ukrainian). Akademiya Nauk Ukrainskoy Radyanskoy Socialistichnoy Respubliki, Kyiv.

Zgorzelski, M.S., 1988. System klasyfikacyjny form ukształtowania powierzchni niżowych obszarów polodowcowych (in Polish). Uniwersytet Warszawski, Warszawa.

http://www.geo.gov.ua/Geological Survey of Ukraine 